\title{
Determination and analysis of synchronous motor's parameters
}

\author{
Aleksandrs Mesnajevs ${ }^{1}$, Andrejs Zviedris ${ }^{2}$ \\ ${ }^{1}$ Riga Technical University (Riga, Latvia), ${ }^{2}$ Riga Technical University(Riga, Latvia) \\ kbl@inbox.lv, aaazzz@eef.rtu.lv
}

\section{INTRODUCTION}

Notion "Parameters of synchronous machines" generally means inductive reactance of these machines (or in some cases of inductance) in different operating conditions. In turn these modes can be divided into three groups - symmetric stationary, transient (or non-stationary) and asymmetrical condition.

In this work the basic statements and the methodological aspects connected with inductive resistance of synchronous motor as input and use of this physical quantity are considered. Different approaches and methods of definition of these resistances are described and analyzed.

\section{PARAMETERS OF SYNCHRONOUS MACHINES}

Armature reaction's direct-axis reactance $\left(X_{a d}\right)$ and quadrature-axis reactance $\left(X_{a q}\right)$, and direct-axis field's synchronous reactance $\left(X_{d}\right)$ and quadrature-axis field's synchronous reactance $\left(X_{q}\right)$ are widely applied to the description of symmetric static mode of the synchronous motor. Active resistance of motors with power $5 \ldots 10 \mathrm{~kW}$ can be ignored, as it is relatively small and practically does not influence on energy transformation process, but only on technical and economic index of the motor (for example, electric losses and efficiency). Besides calculation of active resistance is very easy and creates neither theoretical, neither practical problems.

Wide application of electric machines in power and manufacture began at the end of 19th beginning of 20th centuries. The large amount of works, which have been devoted for calculation and designing of synchronous machines as well as their parameters, has appeared. From these works it is difficult to allocate such in which it is conclusive definition of parameters was considered.

It is necessary to allocate E. Arnold, K. Steinmetz, G. Helmund, V. Rogovsky and works of other authors which have brought in the conclusive contribution to development of the theory of machines of an alternating current, definition of parameters and their use at designing.

Despite of an opportunity to describe and analyze works of later period more detailed, we shall note only a few from them in which questions of principle are considered and separately synchronous machines definition's theoretical and practical aspects are formulated.

It is necessary to allocate especially works A. Blondela in which the two-reaction theory [1] has been formulated and theoretically proved. This theory is considered one of fundamental principles of synchronous machines even in our days. A. Blondel was the first who used transformation variables (a current, a voltage ect.) when from characteristics of a motionless stator winding pass to characteristics which are fix to rotating axes $d$ and $q$.

Electric machines parameters and processes are depending on character of an electromagnetic field, i.e. spatial and time distribution of a field.

Electric machines electromagnetic field in any operating condition can be described by Mahwel's equations. But, the exact solution of these the equation is connected to serious difficulties. It is explained, that the magnetic system will consist of elements at which magnetic properties (the comment ferromagnetic medium and air) very strongly differ. Besides the geometrical form of magnetic system's various elements is rather complex, that results in serious complexities at the account boundary condition. In the end circumstance, that characteristics of ferromagnetic materials used in electric machines are non-linear, results to that the solved differential equations of an electromagnetic field are non-linear, i.e., the equations with various coefficients and because of this they aren't applicable in classical analytical methods.

Considering these and other reasons, the solution of an electromagnetic field's equations is not possible without simplifications and assumptions directed by a problem.

In second half of last century a method of mathematical modelling developed more and more, received the increasing distribution application of for studying electric machines. Numerical methods and accessible computer techniques were more widely entered for their realization.

In the theory of alternating current electric machines winding's EMF $E$ is induced by alternating current's $I$ magnetic field is determined by inductive reactance of this winding [2-4]

$$
X=\frac{E}{I} .
$$


The biggest part of magnetic field's lines creates main magnetic flux which is, while crossing an air gap, completing through the stator's and rotor's magnetic cores and, simultaneously, is linked to stator's and rotor's windings. A small part of a magnetic flux - a leakage flux - completing around stator winding's in slots $\left(\Phi_{\sigma, r}\right)$ and a zone of frontal connection $\left(\Phi_{\sigma, f_{r}}\right)$. The upper harmonics of a stator's winding make a magnetic flux which is completing through an air gap and are poorly linked to a rotor's windings. There for the upper harmonic's flux rank can be included to leakage flux and is called differential leakage flux.

AC machine winding's magnetizing force (MF) creates a periodically varying magnetic field. Such form of a field which makes stator winding's current is schematically shown on Fig.1.
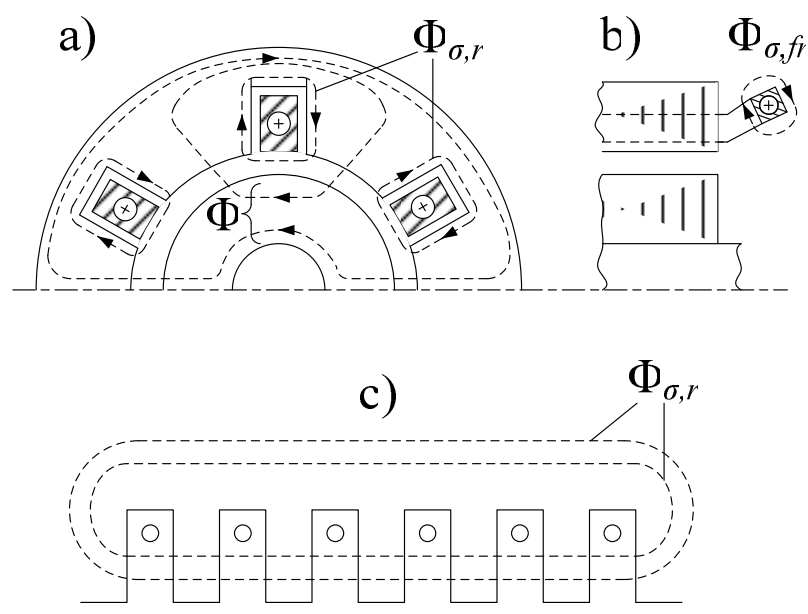

Fig. 1. Magnetic field of AC motor's stator winding. a) main magnetic flux $\Phi$ and slot's leakage flux $\Phi_{\sigma, r} ;$ b) frontal connection parts leakage flux $\Phi_{\sigma, f r}$, c) slot's leakage flux $\Phi_{\sigma}$

Work of an alternating current machines is determined by a fundamental harmonic's magnetic induction $B_{1}$ and induced by this harmonic EMF $E_{1}$, which (see (1)) is possible to describe by inductive reactance

$$
X_{m}=\frac{E_{1}}{I}
$$

which is called basic inductive resistance.

Leakage fields are possible to describe by inductive leakage reactance

$$
X_{\sigma}=X_{\sigma, r}+X_{\sigma, f r}+X_{\sigma, d i f},
$$

where resistance $X_{\sigma, r}, X_{\sigma, f r}, X_{\sigma, d i f}$ - in order a slot, frontal connection and differential leakage reactance.

The stator winding's main inductive reactance can by calculate by equation [2]:

$$
X_{m}=\frac{4 m f}{\pi} \frac{\mu_{0} \pi_{\delta}}{k_{\mu} k_{\delta} \delta} \frac{w_{1}^{2} k_{w 1}^{2}}{p}
$$

The main inductive reactance depends on the following factors:

winding's parameters (phases number $m$, winding coefficient $k_{w b}$, phase coils number $w_{l}$, number $p$ );

the magnetic system's geometrical sizes (pole pitch $\tau$, design length $l_{\delta}$, air gap $\delta$, air-gap factor $k_{\delta}$ );

magnetic circuit's ferromagnetic elements saturation factor $k_{\mu}$.

Inductive reactance $X_{\sigma}$ is practically constant, because leakage flux is completing through the air gap. And on the contrary, the main inductive reactance depends on a magnetic circuit's saturation which, generally defines work of all magnetic field sources (a excitation current, a armature current).

Accordingly, main factors which define synchronous machines inductive reactance are elements of magnetic system, the geometrical sizes and a magnetic circuit's saturation. In "the classical theory" development and improvement process for electric machines plenty approximation methods were developed. These methods, which took into the account those factors, are based on, not always physically enough proved, assumption and simplification were offered. Besides, these assumptions and simplifications cannot recommend the uniform approach to calculation of synchronous machines parameters, especially because of magnetic asymmetry of a synchronous machine salient-pole rotor. Analyzing methods to take into account the saturation which were written by various authors, is possible to conclude, that in a basis of these methods have a similar approaches. These approaches are characterized by how they use: a) vector diagrams, b) a two-reaction method, c) various magnetization's curves, for example $\Phi=f\left(F_{f}\right)$, $\Phi_{a d}=f\left(F_{a d}\right), \quad \Phi_{a q}=f\left(F_{a q}\right)$, including some transitive curves for separate parts of a magnetic circuit; d) a superposition principle with specifications in which take into account the influence of a quadrature-axis and direct-axis armature field's parameters: first of all, on saturation's factors of $k_{\mu d}$ and $k_{\mu q}$.

\section{DEFINITION OF SYNCHRONOUS MACHINES PARAMETERS}

It is necessary to mention $[2,3,5,6]$ in which methods of calculation of various parameters are described. Here, first of all, we shall consider the basic theoretical statements which are full in details and methodologically the most proved (in relation with the account of saturation's influence) were taken a part and summarized by A. Voldek in his works [2.]. We shall simultaneously specify some features and the caused corrections at parameter's definition of which were excitated 
by other authors, for example, A. Vazhnov [5], A. IvanovSmolensky [6].

Taking into account magnetic asymmetry of salient-pole synchronous machines, the main inductive reactance according to the two-reaction theory is a variable quantity which depends on position of a rotor concerning an axis of a stator's magnetic field. These reactances $X_{a d}$ and $X_{a q}$ according to expression (4)

$$
\begin{aligned}
& X_{a d}=\frac{4 m f}{\pi} \frac{\mu_{0} t_{\delta}}{k_{\mu d} k_{\delta} \delta} \frac{w_{1}^{2} k_{w 1}^{2}}{p} k_{a d}, \\
& X_{a q}=\frac{4 m f}{\pi} \frac{\mu_{0} t_{\delta}}{k_{\mu q} k_{\delta} \delta} \frac{w_{1}^{2} k_{w 1}^{2}}{p} k_{a q},
\end{aligned}
$$

where $k_{\mu d}$ and $k_{\mu q}$ - in order, quadrature-axis and direct-axis armature reaction factors of magnetic flux's saturation; $k_{a d}$ and $k_{a q}$ - quadrature-axis and direct-axis armature reaction factors of the field's form.

In a case of non-saturated magnetic system, when $k_{\mu d}=k_{\mu q}=1$ and, having designated reactances $X_{a d \infty}$ un $X_{a q}$ ${ }_{\infty}$, according to (5) and (6)

$$
\begin{gathered}
X_{a d}=\frac{X_{a d \infty}}{k_{\mu d}}, \\
X_{a q}=\frac{X_{a q_{\infty}}}{k_{\mu d}},
\end{gathered}
$$

Precisely to take into account saturation's influence on parameters $X_{a d}$ and $X_{a q}$ of the salient-pole synchronous machine impossible, because of the quadrature-axis armature reaction of magnetic flux $\Phi_{q}$ influences a direct-axis armature reaction $\Phi_{d}$. On this reactance $X_{a d}$ depends not only on $\Phi_{d}$, but also on $\Phi_{q}$. The same is distributed on $X_{a q}$. Saturation factors $k_{a d}$ and $k_{a q}$ in expressions (5) - (6) are different, as well as variables and mutual dependent. Taking into account that there are no comprehensively checked up recommendations for the account of these factors in calculations useing the simplified and approximate methods.

For a basis for this method application it is possible to use the vector diagram shown on Fig. 2. (see, for example [2]), which is constructed as follows

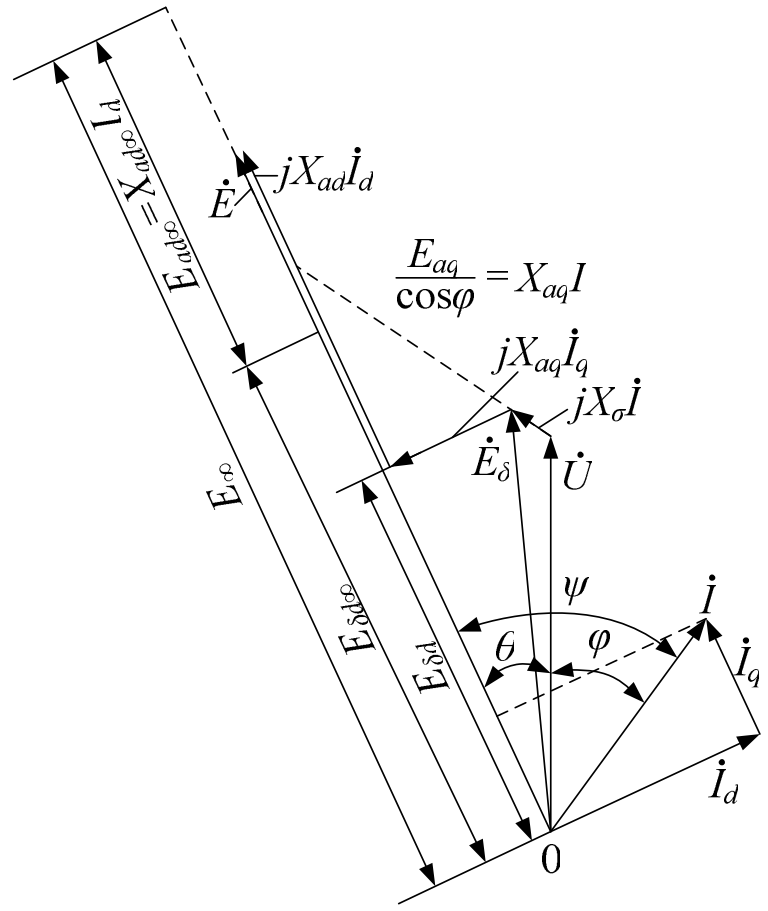

Fig. 2. Voltage phasor diagram of saturated synchronous motor

On given values $U, I \cos \varphi$ and $X_{\sigma}$ find $E_{\delta}$ and after that quantity

$$
X_{a q} I=\frac{X_{a q_{\infty}} I}{k_{\mu q}}=\frac{E_{a q_{\infty}}}{k_{\mu q} \cos \psi}=\frac{E_{a q}}{\cos \psi},
$$

which lay of on continuation of a vector $j X_{\sigma} \dot{I}$, obtaining a direction of a vector $\dot{E}$.

As show researches, a flux $\Phi_{q}$ together with a flux $\Phi_{d}$ create significant saturation of stator's teeth and a pole pitch so $k_{\mu q}=1,2 \ldots 1,6$. In the first approximation this value can be accepted in the specified range, to for example $k_{\mu q}=1,4$. Now in connection with the formula (6) it is possible to consider reactance $X_{a q}$ a determined quantity and, using vector diagram shown on the Fig.2. we can find $\psi, I_{d}, I_{q}, E_{\sigma d}$.

The value $E_{a q_{\infty}} / \cos \psi$ is possible to find from the straightened non-load characteristic in non-saturated regime (3. Fig.), if a stator's current $I$ (or the armature's MF $F_{a}$ ) are led to a excitation's winding [2] where the resulted value are designated by a symbol (').

The magnetic flux in the armature's core and core's saturation depends on $E_{\delta}$, and the main flux in an armature and armature's saturation - on $E_{\delta d}$. Hence, under-load regime saturation in stator's teeth and a pole piece depends on a flux of quadrature-axis reaction $\Phi_{q}$ and it is possible to accept 
approximately, that all saturation of a magnetic circuit is mainly described $E_{\delta}$.

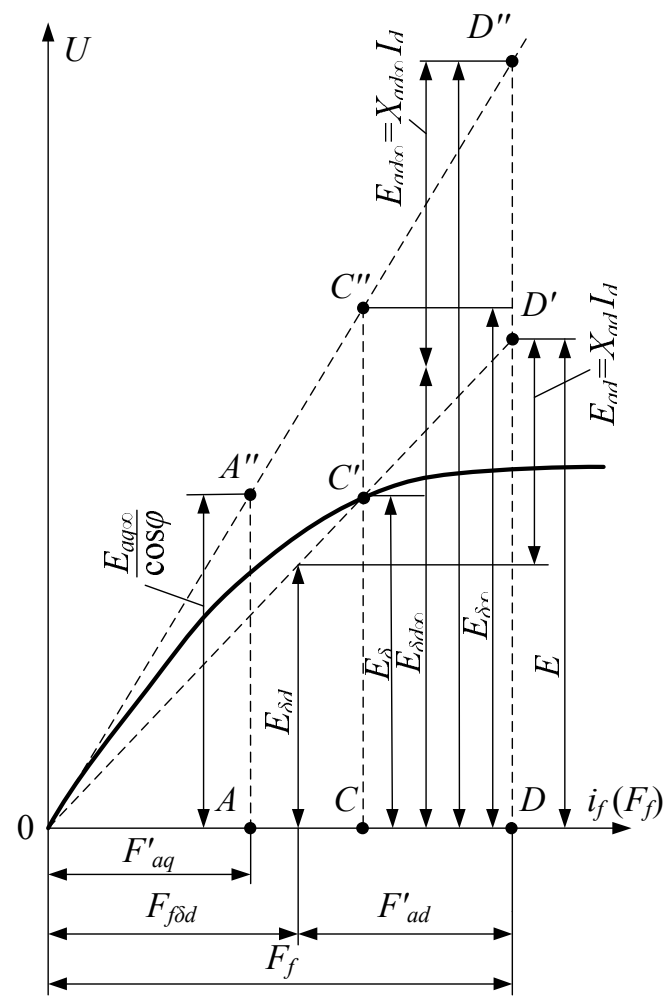

Fig. 3. Salient pole synchronous generator's EMF determination (with saturation taken into account)

If on the vector diagram shown on 3. Fig. to lay of a segment $C C^{\prime}=E_{d}$ and to construct the straightened non-load characteristic for the saturated regime $O C^{\prime} D^{\prime}$, we shall receive, that $k_{\mu d}=C C^{\prime \prime} / C C^{\prime}$. Then reactance $X_{a d}=X_{a d \infty} / k_{\mu d}$ from the formula (7) (or from non-load or fault experiment) is possible to consider as determined value. If on the vector diagram shown on Fig. 2. to lay of a segment $X_{a d} I_{d}$, it is possible to find $E$ and from $D D^{\prime}=E$ (see Fig. 3.) size $F_{f}=O D$ for an examined condition.

After this vector diagrams construction the first approximation when angle $\psi$ and armature current components $I_{d}$ and $I_{q}$ is possible to specify $k_{\mu d}$ and $k_{\mu q}$, and quantities $X_{a d}$ and $X_{a q}$, using some methods, for example, [5, $6]$.

It is necessary to note, that on the vector diagram shown in figure 2 having multiplied vectors $\dot{E}=\dot{E}_{\delta d}+\dot{E}_{a d}=\dot{E}_{\delta d}+X_{a d} \dot{I}_{d}$ and $k_{\mu d}$ we shall receive such vectors which are reduced to the non-load characteristic of not saturated machine $\dot{E}_{\infty}=\dot{E}_{\delta d_{\infty}}+\dot{E}_{a d \infty}=\dot{E}_{\delta d_{\infty}}+X_{a d_{\infty}} \dot{I}_{d}$.
The methods which are described, as example, [5], without paying attention not quite correct theory, in many cases gives satisfactory results.

This method is based on two assumptions: 1) the main harmonic of a direct-axis field practically depends only on a resultant MF of armature $F_{d} ; 2$ ) the main harmonic of a quadrature-axis field is possible to considering separately, but it depends on both $F_{a q}$ and $F_{a d}$ (the similar approach is shown in [6]).

In this case a field of direct-axis reaction induced EMF $E_{a q}$ in the saturated regime is possible for calculating as well as non-saturated regime, i.e. as $E_{a q}=I_{q} X_{a q}$, only finding $X_{a q}$ it is necessary to take into account, that the size of this reactance depends on the main harmonic of a quadrature-axis field.

Hence, constructing of vector diagrams salient pole synchronous machines will not change, if reactance $X_{q_{\infty}}=X_{a q_{\infty}}+X_{\sigma} \quad$ replace with $\quad X_{q}=X_{a q}+X_{\sigma}$. Researches [5] show, that influence of saturation on reactance $X$ is defined with a point on the characteristic of non-load which the resultant MF is equal $F=F_{a}+F_{a q}$. Only the same point and consequently, and reactance $X_{a q}$ is possible to determine only when $F_{d}$ and $F_{a q}$ are known, which are possible to find only by means of the vector diagram. While carrying out practical calculations, are necessary to build these diagrams using iterative procedures. As show such calculations, for synchronous machines with the non-load characteristic nearest to the normal non-load characteristic, two iterations are sufficient, besides in the first iteration reactance $X_{a q_{\infty}}$ can be accepted. In the second iteration value $X_{a q}$ find as $X_{a q}=k_{\mu} X_{a q_{\infty}}$ where $k_{\mu}$ is found, using a point of the non-load characteristic $E=f(F)$ which corresponds to the certain value of a voltage, to for example, rated voltage $E=U_{N}$.

It is necessary to note, that the mentioned methods of taking into account the saturation are not precised and to use them proving theoretical researches are necessary for which are based on numerical methods of mathematical modelling. This method, in comparison with mentioned is work demanding chart analyzing methods, without difficulties, allows to take into account precisely not only a geometrical configuration of magnetic system, but also non-linear characteristics of magnetic materials.

The two-reaction theory is based on a principle of superposition. Use of this theory for the saturated machines is not correct and at the same time does not give those advantages for which it has been developed. Inductive reactance of direct-axis and quadrature-axis reaction in this case lose the evident physical meaning and as it has already been noted, it by complex means are connected among themselves as well as essentially depends on an operating mode. 
As is known, the operating mode of the synchronous machine can be described in four parameters: a armature voltage $U$, a armature current $I$, a phase angle between these values $\varphi$ and a excitation current $I_{f}$. Analyzing and studying characteristics of synchronous machines it is useful to use these four values, further on not connecting them with tworeaction parameters $X_{a d}$ and $X_{a q}$. The mentioned values are easily measured and experimentally checked. Taking into account these reasons it is possible to use, for example, the vector diagram shown on Fig. 4. (see [9]) on which simultaneously with sizes time-dependent $\dot{U}, \dot{I}, \dot{E} \delta, \varphi$, excitation windings, an armature winding and the resultant MF of the main harmonic space vectors $\dot{F}_{a}, \dot{F}_{f}$ and $\dot{F}_{\delta}$ are shown.

Suppose, that, analyzing of the synchronous engine's working modes, it is necessary to determine the excitation current $I_{f}$, which, with the given voltage $U$, load current I provides set angle $\varphi$, i.e., to find functional connection $I_{f}=f(U, I, \varphi)$.

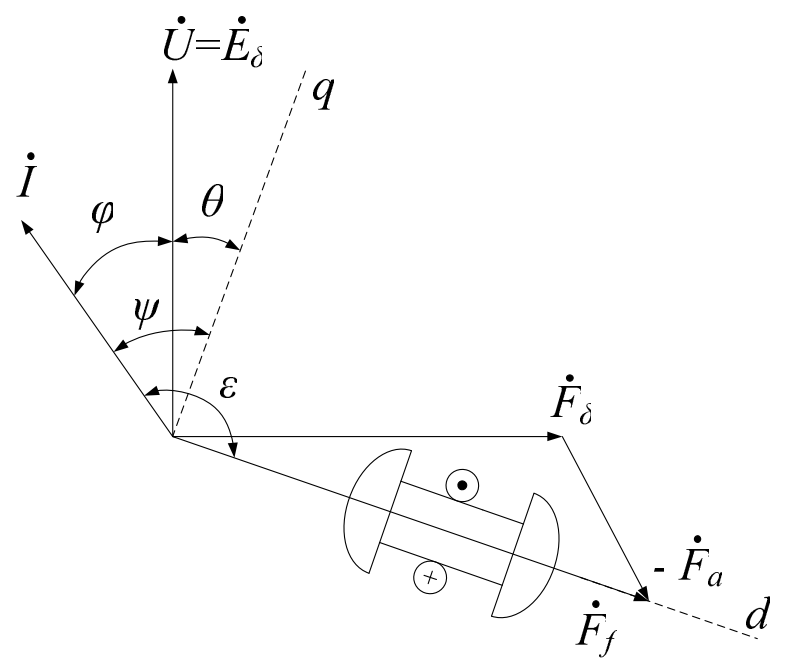

Fig. 4. Phasor diagram ofsynchronous motor (engine mode)

This vector diagram corresponds to the synchronous machine's main equations, which flows from the eclectic and circuit's theory, when in these equations use "integrated" quantities (voltage, current, MF, magnetic flux, EMF, ect.).

Let's examine more detailed the main statement which allow to find above mentioned synchronous machine's characteristics, using results of magnetic field's mathematical modelling, by means of numerical methods. These methods are realised by means of accessible, effective, modern computer programs which, besides, using additional programs-postprocessors allow to adapt the received results to familiar methods of synchronous machine characteristic's definition.
From numerical methods of magnetic fields calculation the most effective and widespread is a finite elements method (FEM). According to this method the main set quantity [8] is the machine's geometrical sizes and its separate elements, excitation winding's and all armature slot's current density that unequivocally defines an angle $\psi$ between quadratureaxis $q$ and the anchor's MF main harmonic's maximum. It is possible to set medium characteristics, a material's magnetisation diagrams of a $B=f(H)$ kind.

Usage of FEM represents many opportunities of a synchronous machine magnetic field's and from it dependent characteristics determination. With FEM it is possible to receive vector magnetic potential as function of spatial coordinates $x_{i}, y_{i}$ for the different (discrete) moments of time $A\left(x_{i}, y_{i}, t_{k}\right)$ and after that, using the basic electromagnetic field's equations [10], to define a magnetic flux, flux linkage, EMF, inductance, inductive reactance $X$, magnetic field's energy $W$, electromagnetic moment $M$, and other quantities.

However it is necessary, to mark, that solving the electromagnetic field's equalizations in a differential form, connection $I_{f}=f(U, I, \varphi)$ it can't be obtained in a direct way, but only with the help of iterative procedures and/or using the mathematical methods with the synthesis of empirical equations for treatment of the data.

To determine of the mentioned functional connection it is possible to use such algorithm:

For set value of a loading current it is set three different values of an excitation current: $I_{f 1}=I_{f \min }, I_{f 3}=I_{f \max }$, $I_{f 2}=\left(I_{f \min }+I_{f \max }\right) / 2$ and three different values of an angle $\quad \varepsilon: \quad \varepsilon_{f 1}=\varepsilon_{f \min }, \quad \varepsilon_{f 3}=\varepsilon_{f \max }$, $\varepsilon_{f 2}=\left(\varepsilon_{f \min }+\varepsilon_{f \max }\right) / 2$, and $3 \times 3=9$ for a combination of these values make mathematical modelling of a magnetic field by a finite elements method. From results of modelling $\left(A_{i, j}=f\left(x_{i}, y_{i}, t_{i}\right)\right)$, in addition to usage of phasor diagram (see Fig. 4), it is possible to find functional connections $U_{i, k}=f_{1}\left(I_{f i}, \varepsilon_{k}\right) \quad$ and $\quad \varphi_{i, k}=f_{2}\left(I_{f i}, \varepsilon_{k}\right) \quad(i=1,2,3 \quad$ and $k=1,2,3)$. These dependences, set in the tabular form, is possible to approximate by analytical expressions polynomial of the second degree

$$
\begin{aligned}
& U=a_{1}+a_{2} I_{f}+a_{3} \varepsilon+a_{4} I_{f} \varepsilon+a_{5} I_{f}^{2}+ \\
& +a_{6} \varepsilon^{2}+a_{7} I_{f}^{2} \varepsilon+a_{8} I_{f} \varepsilon^{2}+a_{9} I_{f}^{2} \varepsilon^{2} \\
& \varphi=b_{1}+b_{2} I_{f}+b_{3} \varepsilon+b_{4} I_{f} \varepsilon+b_{5} I_{f}^{2}+ \\
& +b_{6} \varepsilon^{2}+b_{7} I_{f}^{2} \mathcal{E}+b_{8} I_{f} \varepsilon^{2}+b_{9} I_{f}^{2} \varepsilon^{2}
\end{aligned}
$$

where to determine coefficients $a_{1}, a_{2}, \ldots, a_{9}, b_{1}, b_{2}, \ldots, b_{9}$ is necessary to solve two 9 equation system, if in equations (9) and (10) values $U_{i, k}, \varphi_{i, k}, I_{f i}$ un $\varepsilon_{k}$ are inserted. 
Thus analytical expressions, which describe two functional connections $U=f_{1}\left(I_{f}, \mathcal{E}\right)$ and $\varphi=f_{2}\left(I_{f}, \varepsilon\right)$, which for set modes parameters allow to determine values $I_{f}$ and $\varepsilon$ for this mode, are obtained. To obtain coefficients $a$ and $b$ in matrix form from polynomials (9) and (10) is possible to use

$$
\begin{aligned}
& Z A=U, \\
& Z B=\varphi,
\end{aligned}
$$

where Z - system's quadratic matrix, A and B coefficients $a$ and $b$ colon matrix that are to be obtained, $\mathrm{U}$ and $\varphi-$ matrix of free terms.

Thus analytical expressions (9) and (10), which form two non-linear equations system, are obtained

$$
\begin{aligned}
& U=f_{1}\left(I_{f}, \mathcal{E}\right), \\
& \varphi=f_{2}\left(I_{f}, \mathcal{E}\right),
\end{aligned}
$$

solving which, for set mode's parameters (set $I=$ const, $U=$ const,$\varphi=$ const values) determine conformable values $I_{f}$ and $\varepsilon$.

\section{CONCLUSIONS}

1. The classical synchronous machines theory is based on a superposition principle and in which it is entered direct-axis and quadrature-axis reaction's inductive reactances $X_{a d}$ and $X_{a q}$, is not correct for the saturated machines and does not give those advantages, because of what it was developed.

2. Reactance $X_{a d}$ and $X_{a q}$ essentially depend on magnetic system's saturation.

3. It is not possible precisely to consider saturation's influence of on parameters $X_{a d}$ and $X_{a q}$, as $X_{a d}$ depends not only on direct-axis resultant flux, but also on quadrature-axis flux.

4. Analyzing synchronous machine's characteristics and diagrams is useful not to connect them with the two-reaction theory parameters $X_{a d}$ and $X_{a q}$, but consistently to use the electromagnetic field theory which is realised by a mathematical modelling method.

\section{REFERENCES}

1. A. Blondel. Complements a la theorie de alternateurs a deu reaktions. RGE, 1922. - 203 p.

2. Вольдек А. И. Электрические машины. - Л.: Энергия, 1978. - 832 c.

3. Данилевич Я. Б., Домбровский В. В., Казовский Е. Я. Параметры машин переменного тока. - М.;Л.: Наука, 1965. - 340 с.

4. Зведрис А. П. Электромагнитные расчеты в электрических машинах. Рига: РПИ, 1973. - 74 с.

5. Важнов А. И. Электрические машины. - Л.: Энергия, 1969. - 768 с.

6. Иванов-Смоленский А. В. Электрические машины. - М.: Энергия, 1980. -928 c.

7. Кононенко Е. В. Синхронные реактивные машины. - М.: Энергия, 1970. $-208 \mathrm{c}$.
8. Новик Я. А., Браканский У. К. Дирба Я. А. определение величин, характеризующих режим работы синхронных машин, на основе численного расчета магнитного поля. - Изв. АН Латв. ССР. сер. физ. и. техн. наук,, 1983, 6, с. 102-107.

9. A. Zviedris, A. Podgornovs. „Metodoloǵiskie aspekti sinhrono mašīnu vektoru diagrammu izmantošanai darba režīmu analīzei" // Rīgas Tehniskās universitātes zinātniskie raksti, 4. sēr., Enerǵētika un elektrotehnika. - 16. sēj. (2006), 94-100. lpp.

10. A. Zviedris. Elektrisko mašīnu elektromagnētiskie aprēķini. - Rīga: RTU, 2001. - 72 lpp. 
Mesņajevs A., Zviedris A. Sinhrono mašīnu parametru noteikšanas metodes un to analīze.

\section{KOPSAVILKUMS}

Darbā analizētās sinhrono mašīnu parametru - garenreakcijas $X_{a d}$ un šķērsreakcijas $X_{a q}$ aprēķīnašanas metodes ievērojot magnētiskās sitēmas un to elementu piesātinājumu. Parādīts, ka šī pretestību noteikšanai, izmantojot klasisko sinhrono mašinu teoriju, kuras pamatā ir divu reakciju metore, nav korekta un saistīta ar darbietilpīgiem grafoanalitīskiem aprēķīniem.

Piedāvāta jauna pieeja sinhrono mašīnu darba režīmu kvalitatīvai unkvantitatīvai analīzei, kas balstīta uz konsekventu elektormagnētiskā lauka teorijas izmantošanu, nesastot to ar divu reakcija parametriem $X_{a d}$ un $X_{a q}$. ̌̌āda pieejarealizēta ar magnētiska lauka medelešanas skaitļiskajām metodēm, izmantojot mūsdienu datortēhniķas iespējas.

Mesnyayev A., Zviedris A. Determination and analysis of synchronous motor's parameters.

\section{SUMMARY}

In this work the parameters of synchronous machines are analyzed- direct-axis reaction $X_{a d}$ and quadrature-axis reaction $X_{a q}$. Methods of calculation in view of magnetic system's and its element's saturation are presented.

It is shown that definition of these reactances, using as a basis a two-reaction method, is not correct and connected with work demanding chart analyzing calculations.

The new approach to the qualitative and quantitative analysis of synchronous machine's operating modes which is based on consecutive use of the magnetic field's theory is offered, without it with two-reaction parameters $X_{a d}$ and $X_{a q}$. This approach is realized by means of a magnetic field's modelling using numerical methods with help of modern computers.

Месняев А., Звиедрис А. Методы определения параметров синхронных машин и их анализ. РЕЗЮМЕ

В этой работе анализированы параметры синхронных машин - продольной реакции $X_{a d}$ и поперечной реакции $X_{a q}$. Представлены методы расчёта с учётом насыщения магнитной системы и её элементов.

Показано, что определение этих сопротивлений, используя как основу метод двух реакций, не корректна и связана с работоёмкими графоаналитическими расчётами. Предложен новый подход к качественному и количественному анализу режимов работы синхронных машин, которая основана на последовательном использовании теории магнитного поля, не связывая его с параметрами двух реакций $X_{a d}$ и $X_{a q}$. Этот подход реализован с помощью численных методов моделирования магнитного поля с использованием современных возможностей компьютерной техники. 